ASLI QoL 2021

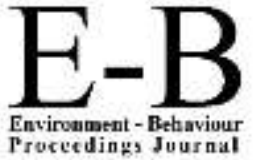

Proceeding, Juurnal

\title{
AQoL2021LangkawiIsland
}

https://www.amerabra.org; https://fspu.uitm.edu.my/cebs; https://www.emasemasresources.com/ $5^{\text {th }}$ ABRA International Conference on Quality of Life Holiday Villa Langkawi, Langkawi Island, Malaysia, 15-16 Dec 2021

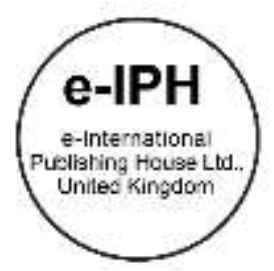

\section{Media and Funding: A qualitative study of Malaysian Social Welfare NGOs}

\author{
Nurliana Zahira Zaharrudin, Azzarina Zakaria \\ Faculty of Business and Management, \\ Universiti Teknologi MARA (UiTM),40450 Shah Alam, Selangor Darul Ehsan, Malaysia \\ nurlianazahirazaharrudin@gmail.com, azzarina@uitm.edu.my \\ Tel: 011-23650387
}

\begin{abstract}
This study explores the extent of media facilitates Malaysian Social Welfare Non-Governmental Organizations (SWNGOs) to acquire funding. Malaysian SWNGOs rely on external funding to support their operation, but this external funding is uncertain and limited. The number of registered Malaysian NGOs has increased recently. For this reason, acquiring funding has become more challenging for Malaysian SWNGOs. Through semi-structured interviews with 6 Malaysian SWNGOs, the study found that television is a dominant media platform to acquire funding. Also, an official website, Facebook, Instagram, and WhatsApp were prominent platforms for most Malaysian SWNGO to acquire funding.
\end{abstract}

Keywords: Media; Funding; Malaysian SWNGO

eISSN: 2398-4287@ 2021. The Authors. Published for AMER ABRA CE-Bs by e-International Publishing House, Ltd., UK. This is an open access article under the CC BYNC-ND license (http://creativecommons.org/licenses/by-nc-nd/4.0/). Peer-review under responsibility of AMER (Association of Malaysian Environment-Behaviour Researchers), ABRA (Association of Behavioural Researchers on Asians/Africans/Arabians) and CE-Bs (Centre for Environment-Behaviour Studies), Faculty of Architecture, Planning \& Surveying, Universiti Teknologi MARA, Malaysia.

DOI: https://doi.org/10.21834/ebpj.v6i18.3064

\subsection{Introduction}

Non-governmental organisations (NGOs) carry out voluntary services and humanitarian activities, being the advocate for justice, a voice out concerns among citizens to the government, organise programmes for societal awareness, and encouraging the government and corporations to work at the community level (United Nations [UN], 2003). The role of NGO is to influence government policy implementation for the betterment (Gemmill \& Bamidele-Izu, 2002). For example, Pertubuhan Jamaah Islah Malaysia (JIM), a religionoriented NGO, advocates human rights since the JIM members believe this is an integrated and pertinent aspect of good governance. As a result of their effort, the Internal Security Act (ISA) was abolished and replaced by the Security Offences (Special Measures) Act 2012 (Malik, 2014).

NGOs need adequate funding for their survival (Masdar, Kadir \& Bahar, 2017). Previous studies have identified some NGO funding alternatives, such as maintaining relationships with donors and collaborating with donors (Avery et al., 2020). Zhong and Lin (2017) highlight that many NGOs use media in their work, but the studies on media use in funding acquisition are limited. Therefore, this study explores the extent of the use of media in acquiring funding among social welfare NGOs (SWNGOs) in Malaysian.

\subsection{Literature Review}

eISSN: 2398-42870 2021. The Authors. Published for AMER ABRA cE-Bs by e-International Publishing House, Ltd., UK. This is an open access article under the CC BYNC-ND license (http://creativecommons.org/licenses/by-nc-nd/4.0). Peer-review under responsibility of AMER (Association of Malaysian Environment-Behaviour Researchers), ABRA (Association of Behavioural Researchers on Asians/Africans/Arabians) and CE-Bs (Centre for Environment-Behaviour Studies), Faculty of Architecture, Planning \& Surveying, Universiti Teknologi MARA, Malaysia.

DOI: https://doi.org/10.21834/ebpj.v6i18.3064 
Media is a communication tool to convey information (Lovari \& Bowen, 2019). There are two categories of media: mass media and social media. Mass media is a conventional approach to disseminate messages to a broader audience via a one-way interaction (Apuke, 2016). In contrast, social media is a modern approach used in this new era. It involves a two-way communication that enables users to create and share information to connect with people worldwide (ibid). It encompasses virtual content transmitted using advanced technologies such as the internet, computer networks, and mobile phones (Appel et al., 2019). Social media has advantages over mass media in terms of how information can be disseminated quickly to the public. In addition, the audience can respond to the information shared through social media faster than the message conveyed via mass media (Odun \& Utulu, 2016). Mass media uses newspapers, magazines, television, radio, billboards, banners, and pennants to spread information (Burnett et al., 2017). Facebook, Instagram, Twitter, YouTube, Telegram, WhatsApp, and WeChat are examples of social media (ibid). Suresh, Øyna, and Munim (2020) claimed that today's generation places a higher emphasis on social media to obtain information than mass media.

Media is a platform used to influence public attitude and behaviour to benefit organisations (Girish \& Ghosh, 2020). The notion that the media can garner public attention and influence the attitude and behaviour of the public is consistent with the Hypodermic Needle Theory (HNT) (Nwabueze \& Okonkwo, 2018). This theory assumes that messages conveyed via media bring impact to the audience who are unaware of the information. Therefore, media can influence the attitude and behaviour of the public to elicit the desired response (ibid). In this study, the purpose of media is to disseminate information to the public to solicit funds. NGOs use emotional photos or videos to influence public perception of the message conveyed (Zhang \& Skoric, 2019). The emotional aspect of the photos and videos can influence the public to donate.

Funding for NGOs is uncertain and limited, and donors must engage in specific measures of financial viability to provide funding (United States Aid, 2006). However, funding becomes critical due to the increasing number of NGOs, resulting in greater competition for funding (Boomsma \& O'Dwyer, 2018). The financial constraints would affect the NGOs' work, and some NGOs has ceased the operation (Banks, Hulme, \& Edwards, 2015). The study found that competition implicitly disrupts NGOs funding activities due to environmental forces. Therefore, Ajina (2019) reported that media is essential to NGOs operations and serves as a platform to acquire funding.

Previous qualitative research focuses on NGO social engagement and accountability for fund sustainability, NGO funding programmes, NGO funding priorities, and NGO funding reporting (Gazzola et al., 2019; Shava, 2020; Chaudhry \& Heiss, 2020; Yang \& Simnett, 2020). However, qualitative studies on the use of media for funding are limited (Zhang \& M. Skoric, 2019). Therefore, this study aims to fill this gap. Additionally, there are 10 registered NGO groups in Malaysia, namely social welfare, social work, religion, youth and sports, culture and arts, human rights, professional, mutual benefit, commerce, and safety (Registrar of Society [ROS], 2020). Social welfare makes up the majority of NGOs to address issues encountered by the vulnerable people, the poor and victims of natural disasters (Islam, 2015). For instance, if studies focus more on religious and human rights NGOs in Malaysia (Malik, Safarudin \& Mat, 2018; Selvanathan, Khoo, \& Lickel, 2019), then only a few studies focus on SWNGOs through media context (Mohamad Ashray, 2018). Nevertheless, SWNGOs play an important role in resolving the underlying issues in the Malaysian community. Thus, this study does carry much weight to the body of knowledge.

\subsection{Methodology}

The participants of this study were the decision-makers or executors for funding acquisition and affiliated with registered Malaysian SWNGOs in Selangor. The researcher retrieved the list of Malaysian SWNGOs in Selangor from ROS and approached more than ten SWNGOs in the state for an interview. Only six SWNGO representatives agreed to participate in this study. Of the six participants, two were between 57 and 67 years old, and four were between 30 and 40 years old.

Semi-structured interviews were conducted with four NGO board members and two staff members. The semi-structured interviews explored the participants' thoughts and experiences concerning the topic studied (DeJonckheere \& Vaughn, 2019). The researcher prepared the pre-determined themes before conducting the interviews. Then, interview questions were developed from the predetermined themes to guide the participants during the interviews.

Two external experts with experience and knowledge of NGOs and experience in managing and allocating funds validated the predetermined themes. Then, pilot interviews were conducted with three NGO representatives from two social welfare NGOs and one religious NGO in Malaysia for validation. By combining external experts and pilot interviews, well-validated interview questions can be developed to help the researcher obtain rigorous and comprehensive interview data to address the research problem.

The interviews were conducted in two ways: face-to-face with audio recording and online via the Webex application. In addition, the researcher allowed the participants to speak in Malay or English to enhance the connection between the researcher and the participants and understand the topic better. Each interview lasted between 40 and 90 minutes. The interviews were recorded after the participants had signed an informed consent form. Finally, data were analysed using a thematic analysis technique.

\subsection{Findings}

\subsection{Media Types}

The findings in Table 1.1 show that the NGOs used five types of media to acquire funding: television (mass media) and official website, Facebook, Instagram, and WhatsApp (social media). 


\begin{tabular}{|c|c|c|c|c|c|c|}
\hline NGO & NG01 & NGO2 & NGO3 & NGO4 & NGO5 & NGO6 \\
\hline Media types & & & & & & \\
\hline Television & $\sqrt{ }$ & $\sqrt{ }$ & $\sqrt{ }$ & $\sqrt{ }$ & None & $\sqrt{ }$ \\
\hline Official Website & None & $\sqrt{ }$ & None & $\sqrt{ }$ & $\sqrt{ }$ & $\sqrt{ }$ \\
\hline Facebook & None & $\sqrt{ }$ & None & $\sqrt{ }$ & $\sqrt{ }$ & $\sqrt{ }$ \\
\hline Instagram & None & $\sqrt{ }$ & None & $\sqrt{ }$ & $\sqrt{ }$ & $\sqrt{ }$ \\
\hline WhatsApp & None & $\sqrt{ }$ & None & $\sqrt{ }$ & $\sqrt{ }$ & $\sqrt{ }$ \\
\hline
\end{tabular}

The findings show that all the participants used the media in their NGO operations. However, the most frequently used is television. It was also found that the participants frequently used official websites, Facebook, Instagram, and WhatsApp. Half of the participants used all the media types.

\subsection{Media Function}

The study found that the function of the media is to disseminate information to the public. All the participants disseminated information about their NGOs' activities and campaigns through the media. For example, the NGO5 representative stated that when the organisation conducts activities such as flood relief missions, promotional posters are created and posted on social media to disseminate information about the mission. NGO6 representative also stated that the NGO broadcasts information on television channels to promote their activities and introduce their products to the public. The information disseminated through the media can attract the public's attention and help in soliciting funds. For example, the participants used Facebook advertising to promote their activities to the public. NGO2 representative informed that Facebook advertising has a section for uploading photos, videos, or articles. NGOs can select the donors by gender, age, and background, making it easier to identify the potential donors. Thus, the information provided through Facebook advertising can attract previous and new donors. In addition, some participants actively used Instagram to attract public attention. NGO2 representative claimed Instagram to be an ideal platform to promote NGO activities. Although only photos and videos can be posted on Instagram, publishing photos can attract public attention and gain donations. Participants also added their official website's uniform resource locators (URL) on Facebook and Instagram. A click on the URL brings visitors to the NGO's website to learn more about the NGO's background and activities. NGO4 representative claimed that the NGO's official website has a professional look to attract viewers and includes a section for donations. The NGOs also used the WhatsApp platform to attract public attention. For example, the NGO5 representative explained that it creates attractive sentences, photos, and colours on flyers and posters and shares them through WhatsApp. The WhatsApp platform is an easy and convenient means to share information or messages with donors or potential donors, making it easier for NGOs to attract public attention and donations. Apart from Facebook, Instagram, the official website, and WhatsApp, television is another type of media that can attract public attention. For example, the NGO2 representative explained that the NGO has advertised on television channels such as AlHijrah and utilised the Bernama TV broadcasting slot. Such an approach allows them to draw people's attention to their activities.

\subsection{Media Impact}

There are three media impacts on NGOs: increasing their visibility, influencing public perceptions of NGOs, and influencing public action on funding.

\subsubsection{Increasing the Visibility of NGOs}

The media enhances the visibility of NGOs in the market, where initially, many people ignored the existence of NGOs and the information they provided. For example, the NGO3 informed that after the NGO invited reporters to promote its programmes in the media, people started following the NGO's programmes. Thus, the media does help to increase the visibility of NGOs to the public. In addition, the NGO6 said that:

"We have commercial our campaigns on social media like Facebook, Instagram, and website frequently to attract viewers. We can insert the link for donation on social media platforms. As a result, our NGOs and campaigns are visible to the public and donate."

\subsubsection{Influencing Public Perception}

The finding reveals that the information disseminated through the media can influence public perceptions of NGOs. For example, the NGOs used photos, videos, and articles to convey emotional messages on their programmes to influence public perception of the NGOs. NGO2 mentioned that:

"We have a content writer who creates sentences related to the programmes, campaigns, and fundraising purpose through media to influence the public perception of NGOs. Otherwise, we have photos or videos to appeal to others' feelings and emotions about the programmes to acquire funds. Thus, using multiple functions in media tools can influence public perception."

This statement implies that the media is a powerful platform for NGOs to influence the public's perception of them.

\subsubsection{Influencing Public Action}

Surprisingly, the study found that television has a long-term impact on NGOs. The participants informed that based on their experience, television could influence the public to provide continuous funding to NGOs. NGO6 said: 
"Currently, there are no campaigns on television. However, we still have donations. Some have donated every month even though we have no programmes!"

This statement shows that the activities promoted on television have a substantial impact on funding. However, some participants had an opposite experience where television had a negative impact on their fund acquisition efforts. NG01 explained:

"Often, we invite the media to our programmes, but it does not work. For example, recently, we had a programme at the University of Malaya (UM), and we invited the media, but we have to pay for the media."

The participants informed that their NGOs used the official website, Facebook, Instagram, and WhatsApp to influence the public to donate. NGO6 said:

"Nowadays, he [the NGO's director] uses social media to get funding. So when he posted a WhatsApp message, and the message was viral, it appealed for donations. After a few seconds, [MYR] ten thousand was in our account, just through WhatsApp."

Three participants used both mass media and social media platforms to raise funds. NG06 explained":

"We promoted our programmes through television, and we are active on social media. For example, we always update our official website and update the programme on Facebook and Instagram. So, people can easily allocate funds when we are active on media platforms. Although we have had no programmes on television for a long time because of the Malaysian Government Movement Control Order (MCO), however, we still got funded."

The statement was supported by an NGO4, who stated:

"During MCO, social media is the best platform to get funding."

Based on the interview responses from the participant, both types of media platforms are essential in NGOs' funding activities.

\subsection{Discussion}

In 2019, 2.95 billion people were active on social media worldwide. Statista (2021) reported that the number is predicted to increase to nearly 3.43 billion by 2023 . Facebook is the largest social media in the world. The number of active Facebook users increased to approximately 3 billion in 2021, making it the most popular social media. Apart from Facebook, Instagram and WhatsApp are the most popular social media. There are one billion monthly active Instagram users (ibid). WhatsApp is also the leading mobile messaging application compared to WeChat and Telegram. Two billion users access WhatsApp every month.

Ifigeneia and Dimitrios (2018) found that many organisations, including NGOs, actively used Facebook, Instagram, and WhatsApp for their work. These platforms are used to commercialise products and inform the public about events. In addition, most NGOs also have an official website (ibid). It is a place where viewers can view the organisation's background and activities. It also allows viewers to interact with the organisation and obtain more information about the organisation (Bernal Jurado et al., 2018). Thus, Facebook, Instagram, WhatsApp, and the official website are recognised as the frequently used social media platforms in the digital world.

However, this study's findings demonstrate that television is the most frequently used media among Malaysian SWNGOs. Malaysia is a developing country with a high proportion of the middle-income population. While a report by the World Bank (2016) shows that social media is spreading rapidly, nearly 2 billion people in developing countries do not own smartphones or computers. Nearly 60 per cent of the world's population have no access to the internet (ibid). Moreover, Mertzanis and Said (2019) found the technological infrastructure in developing countries moderately developed. Ferri, Grifoni, and Guzzo (2020) argued that access to smartphones and computers is challenging in rural areas of developing countries due to low electricity availability and internet connectivity. Thus, in rural areas, the information conveyed through social media is limited to mass media. It is, therefore, not surprising that television is still relevant in Malaysia.

Furthermore, the findings depend to some extent on the background of the participants. For example, some of the participants are the baby boomer generation. Baby boomers were born between 1946 and 1964 (Towner \& Munoz, 2016). These people rely on faceto-face communication where body language and non-verbal cues are essential (Walmsley, 2011). Despite the advent of digital technology, baby boomers are resistant to change (Venter, 2017). However, baby boomers struggle to adapt to technological change, and some do not appreciate the new technology. Towner and Munoz (2016) also found that baby boomers only focus on mass media. Thus, it is not surprising that television is the most popular media in this study.

This study's participants also included Generation Y. Generation Y refers to people born between 1981 and 1999 (Poláková \& Klímová, 2019). This generation receives early and frequent exposure to technology (ibid). Some studies found Generation $Y$ to be actively engaged in social media (Bolton et al., 2013). Kinski (2017) found that Generation Y actively contributes content to social media and prefers to stay connected and multitask through technology. Zheng and Cheok (2011) found that $99 \%$ of Generation $Y$ has an active profile on social media platforms.

The media is frequently used to promote NGOs' activities. Several empirical studies also support this finding. For example, social media plays a vital role in commercialising NGOs' activities and introducing NGOs to the public, thereby improving the NGOs' image (Akatay et al., 2017). NGOs can also use their websites to state their mission and promote their activities to the public (ibid). Numerous studies have suggested that information disseminated through the media can attract public attention (Zhong \& Lin, 2017). For example, text features can appeal to readers' emotions and increase readers' attraction and perception (Singh, 2014).

The findings show that messages disseminated through social media can influence public perception. For example, Bria (2013) asserts that a website enhances the organisation's credibility and looks professional to viewers. Tonetti (2019) found that NGOs publish 
articles about their activities, use catchy words, and share emotional photos and videos to influence their public perception through social media. Further, Jang-Jaccard and Nepal (2014) discovered that internet connectivity has significantly increased social media usage, such as WhatsApp. WhatsApp messages concerning NGO activities can be disseminated widely to individuals or particular groups and are also created to influence public perception and deliver messages easily and quickly (Farooq, 2018).

Finally, the findings reveal that the media influences public action by encouraging people to support NGOs financially. This finding is supported by previous research on the influence of media on NGOs. For example, Barnes and Andonian (2011) found Facebook the dominant media for NGOs to raise funds. Bocquet, Cotterlaz-Rannard, and Ferrary (2020) found that the World Wildlife Fund (WWF) raises funds through social media, including its official website and Facebook. WWF has conducted many campaigns through social media and has been successful in fundraising. Some studies have claimed that mass media has little influence on public action (Saxton \& Wang, 2014). Many studies have highlighted that mass media is no longer actively used for fundraising with the increasing use of social media (Hennig-Thurau et al., 2010; Body \& Breeze, 2016). Among the baby boomers in Malaysia, social media usage is limited compared to mass media (Ting et al., 2018). However, the present study found that television (mass media) predominantly influences donors to donate. This finding is consistent with the proposition by Hackworth and Kunz (2010) that NGOs should consider using the mass media to raise funds through a robust social media presence.

\subsection{Conclusion}

This study has explored media use in funding acquisition, which has been overlooked by studies on media and funding (Fredheim \& Figenschou, 2020). The concept of HNT is appropriate in this study, in which the NGOs' messages disseminated through the media influenced donors' attitudes and behaviour in providing funds. The findings have implications at theoretical, methodological, and practical levels. Theoretically, NGOs employ several alternatives to raise funds, including collaboration and maintaining relationships with donors. However, many NGOs use media for their operations, specifically for fundraising. Therefore, this study provides additional insights to NGOs on media usage in funding acquisition. Methodologically, many empirical studies on NGOs in Malaysia focus on NGOs in general, religion and human rights (Rashid, 2015; Malik, Safarudin, \& Mat, 2018). However, few studies have focused on SWNGOs, making it is necessary to study. Practically, mass media and social media should be used to solicit funds. Waters, Tindall and Morton (2010) asserted that NGOs should not only use mass media to access funding. However, social media are not expected to replace mass media in Malaysia. Both platforms co-exist and complement each other in funding acquisition (Salman et al., 2011). This notion is in line with the study of Bria (2013), which found that Greenpeace NGO actively used social media and mass media for its campaigns and appeals for funding.

This study has several limitations. First, the six interview participants represented NGOs that conduct activities for and address the problems of vulnerable groups, particularly elderly citizens, women, and single mothers. However, there are many other vulnerable groups addressed by Malaysian SWNGO. Thus, the findings should be interpreted cautiously, as each SWNGO serves a different function. Next, due to the small number of participants, the findings have limited applicability to the broader Malaysian SWNGOs with different missions, which may take a different stance and solicit funding in their ways. Therefore, the findings should be interpreted with caution.

This study raises the possibility for further funding acquisition research in the future. Future research could focus on other Malaysian SWNGOs that empower other vulnerable groups and nine other types of Malaysian NGOs with different missions. In addition, there are Malaysian NGOs that focus on religious aspects, including Islam, Buddhism, Hinduism, and Christianity. It would be interesting to study how Malaysian NGOs use the media to solicit funds for different religions, which may unearth varying funding trends.

\section{Acknowledgements}

This research is funded by the Institute of Research Management Centre (RMC), "Geran Insentif Penyeliaan (GIP): 600-RMC/GIP 5/3 (003/2021)," internal research grant from Universiti Teknologi MARA, Shah Alam Selangor, Malaysia.

\section{References}

Ajina, A.S., (2019). The perceived value of social media marketing: an empirical study of online word-of-mouth in Saudi Arabian context. Entrepreneurship and Sustainability Issues 6(3): 1512-1527. https://doi.org/10.9770/jssi.2019.6.3(32)

Akatay, A., Hacıoğlu, G., Kıray, A. ve Özdemir, S., (2017). A qualitative research on NGOs' use of socıal media in Çanakkale, ss. 63-80. Route Educational and Social Science Journal 4(7)

Appel, G., Grewal, L., Hadi, R., \& Stephen, A. T., (2019). The future of social media in marketing. Journal of the Academy of Marketing Science. doi:10.1007/s11747-01900695-1

Apuke, O.D., (2016). Social and traditional mainstream media of communication: Synergy and variance perspective. New Media and Mass Communication. 83-86.

Ashray, FSBM., (2018). Social welfare services in Malaysia: The role of government. Advances in Social Science, Education and Humanities Research, $191,427-436$.

Avery, M. D., Jennings, J. C., Germano, E., Andrighetti, T., Autry, A. M., Dau, K. Q., ... Woodland, M. B., (2020). Interprofessional education between midwifery students and obstetrics and gynecology residents: An American College of nurse-midwives and American College of obstetricians and gynecologists collaboration. Journal of 
Midwifery \& Women's Health. doi:10.1111/jmwh.13057

Banks, N., Hulme, D., \& Edwards, M., (2015). NGOs, states, and donors revisited: Still too close for comfort? World Development, 66, 707-718. doi: 10.1016/j.worlddev.2014.09.028

Barnes, N. G., \& Andonian, J., (2011). The 2011 fortune 500 and social media adoption: Have America's largest companies reached a social media plateau? University of Massachusetts. Dartmouth: Center for Marketing Research, Charlton College of Business.

Bernal Jurado, E., Mozas Moral, A., Medina Viruel, M., \& Fernández Uclés, D., (2018). Evaluation of corporate websites and their influence on the performance of olive oil companies. Sustainability, 10(4), 1274. doi:10.3390/su10041274

Bocquet, R., Cotterlaz-Rannard, G., \& Ferrary, M., (2020). How do NPOs get funding? A business model perspective based on the conversion of symbolic capital. Nonprofit and Voluntary Sector Quarterly, 089976402092591. doi:10.1177/0899764020925912

Body, A., \& Breeze, B., (2016). What are 'unpopular causes' and how can they achieve fundraising success? International Journal of Nonprofit \& Voluntary Sector Marketing, 21 (1), 57-70, doi:org/10.1002/nvsm.1547

Bolton, R. N., Parasuraman, A., Hoefnagels, A., Migchels, N., Kabadayi, S., Gruber, T., ... Solnet, D., (2013). Understanding Generation Y and their use of social media: a review and research agenda. Journal of Service Management, 24(3), 245-267. doi:10.1108/09564231311326987

Boomsma, R., \& O'Dwyer, B. (2018). Constituting the governable NGO: The correlation between conduct and counter-conduct in the evolution of funder-NGO accountability relations. Accounting, Organizations and Society. doi:10.1016/j.aos.2018.05.012

Bria (F)., (2013). Social media and their impact on organisations: building firm celebrity and organisational legitimacy through social media. Imperial College London.

Burnett, W. C., Wattayakorn, G., Supcharoen, R., Sioudom, K., Kum, V., Chanyotha, S., \& Kritsananuwat, R., (2017). Groundwater discharge and phosphorus dynamics in a flood-pulse system: Tonle Sap Lake, Cambodia. Journal of Hydrology, 549, 79-91.

Chaudhry, S., \& Heiss, A., (2020). Dynamics of international giving: How heuristics shape individual donor preferences. Nonprofit and Voluntary Sector Quarterly 1-25

DeJonckheere, M., \& Vaughn, L. M., (2019). Semi structured interviewing in primary care research: a balance of relationship and rigour. Family Medicine and Community Health, 7(2), e000057. doi:10.1136/fmch-2018-000057

Farooq, G., (2018). Politics of fake news: How whatsApp became a potent propaganda tool in India. Media Watch 9 (1) 106-117. doi: 10.15655/mw/2018/v9i1/49279

Ferri, F., Grifoni, P., \& Guzzo, T., (2020). Online learning and emergency remote teaching: Opportunities and challenges in emergency situations. Societies, 10(4), 86. doi:10.3390/soc10040086

Fredheim, N. A. G., \& Figenschou, T. U., (2020). Changing priorities, hybrid campaigns: Interest groups' perceptions of gains and risks in the new media landscape. Interest Groups \& Advocacy, 9(2), 197-219. doi:10.1057/s41309-020-00089-7

Gazzola, P., Amelio, S., Papagiannis, F., \& Michaelides, Z., (2019). Sustainability reporting practices and their social impact to NGO funding in Italy. Critical Perspectives on Accounting. doi:10.1016/j.cpa.2019.04.006

Gemmill, B., \& Bamidele-Izu, A., (2002). The role of NGOs and civil society in global environmental governance. Global environmental governance, 1-24.

Girish, G.P., \& Ghosh, S., (2020). Dynamics between digital visibility through social media marketing and crowdfunding: Path to succeed in entrepreneurship. Indian Journal of Finance and Banking, 4(2), 28-37.

Hackworth, B.A. \& Kunz, M.B., (2010). Health care and social media: building relationships via social networks. Academy of Health Care Management Journal, 6(1), 5568.

Hennig-Thurau, T., Malthouse, E. C., Friege, C., Gensler, S., Lobschat, L., Rangaswamy, A., \& Skiera, B., (2010). The impact of new media on customer relationships. Journal of Service Research, 13(3), 311-330. doi:10.1177/1094670510375460

Ifigeneia, M., \& Dimitrios, A., (2018). Globalization, social media and public relations: A necessary relationship for the future? in The Economies of the Balkan and the Eastern European Countries in the changing World, KnE Social Sciences, 309-325. DOI 10.18502/kss.v3i10.3546

Islam, M. R., (2015). Rights of the people with disabilities and social exclusion in Malaysia. International Journal of Social Science and Humanity, 5(2), $171-177$. doi:10.7763/IJSSH. 2015.V5.447

Jang-Jaccard, J., \& Nepal, S., (2014). A survey of emerging threats in cybersecurity. J. Comput. Syst. Sci. 80 (5), 973-993. DOI:http://dx.doi.org/10.1016/j.jcss.2014.02.005

Kinski, N., (2017). A perfect match: Influencer marketing and the beauty industry. Retrieved February 10, 2019, from https://upfluence.com/influencermarketing/influencermarketing-beauty-industry

Lovari, A., \& Bowen, S. A., (2019). Social media in disaster communication: A case study of strategies, barriers, and ethical implications. Journal of Public Affairs, e1967. doi:10.1002/pa.1967

Malik, M., (2014). Islamic movement and human rights: Pertubuhan Jamaah Islah Malaysia's involvement in the "Abolish Internal Security Act Movement," $2000-2012$. Intellectual Discourse, 22(2), 139-165.

Malik,M., Safarudin, S., \& Mat, H., (2018). Islamic NGO as another actor of civil society: the case of Pertubuhan ikram malaysia (IKRAM). Ulum islamiyyah, $23,20-34$. 
Masdar, N.M., Kadir, S. U. S.A., \& Bahar, I.A.A. (2017). The role of NGO's employees towards trust development in donor. World Journal of Management and Behavioral Studies, 5 (3), 57-64. doi: 10.5829/idosi.wjmbs.2017.57.64

Mertzanis, C., \& Said, M., (2019). Access to skilled labor, institutions and firm performance in developing countries. International Journal of Manpower. doi:10.1108/ijm$11-2017-0301$

Nwabueze, C., \& Okonkwo, E., (2018). Rethinking the Bullet Theory in the digital age. International Journal of Media, Journalism and Mass Communications (IJMJMC). 4 (2). $1-10$.

Odun, O., \& Utulu, A. U., (2016). Is the New Media Superior to the Traditional Media for Advertising. Asian Journal of Economic Modelling, 4(1), 57 69. doi:10.18488/journal.8/2016.4.1/8

Poláková, P., \& Klímová, B., (2019). Mobile technology and generation Z in the English language classroom - A Preliminary Study. Education Sciences, 9(3), 203. doi:10.3390/educsci 9030203

Rashid, N.A.Z., (2019). Human resource practices in a non-governmental organization (Ngo): A case study at Malaysian Nature Society (MNS). Univertsiti Utara Malaysia

Registrar of Society Malaysia., (2020). Statistik pendaftaran pertubuhan (2017-2020). JABATAN PENDAFTARAN PERTUBUHAN MALAYSIA (ros.gov.my). [Access online 16 June 2020]

Salman, A., Ibrahim, F., Abdullah, M.Y., Mustaffa, N., \& Mahbob, M.H., (2011). The impact of new media on traditional mainstream mass media. The Innovation Journal: The Public Sector Innovation Journal, 16(3), 2-11.

Saxton, G.D. and Wang, L., (2014). The social network effect: The determinants of giving through social media. Nonprofit and Voluntary Sector Quarterly, 43(5), 850-868.

Selvanathan, H. P., Khoo, Y. H., \& Lickel, B., (2019). The role of movement leaders in building intergroup solidarity for social change: A case of the electoral reform movement in Malaysia. European Journal of Social Psychology. doi:10.1002/ejsp.2598

Shava, E. (2020). Financial sustainability of NGOs in rural development programmes. Development in Practice, 31(3), 393-403. doi:10.1080/09614524.2020.1853059

Singh, K., (2014). Servant leadership in non- governmental organizations (NGOs). Journal of Administrative Science, 11(1).

Statista., (2021). Facebook: number of monthly active users worldwide 2008-2021. • Facebook MAU worldwide 2021 | Statista [Access online 16 August 2021] Suresh, K, Øyna, S \& Munim, ZH., (2020). Crowdfunding prospects in new emerging markets: the cases of India and Bangladesh. 197-318.

Ting, H., Lim, T.-Y., de Run, E. C., Koh, H., \& Sahdan, M., (2018). Are we Baby Boomers, Gen X and Gen Y? A qualitative inquiry into generation cohorts in Malaysia. Kasetsart Journal of Social Sciences, 39(1), 109-115. doi:10.1016/j.kjss.2017.06.004

Tonetti, A., (2019). Fundraising and online marketing: How social media have an impact on the growth of a charity organization. ISCTE - Lisbon University Institute (Iscte - Instituto Universitário de Lisboa).

Towner, T., \& Lego Munoz, C., (2016). Boomers versus millennials: Online media influence on media performance and candidate evaluations. Social Sciences, 5(4), 56. doi: $10.3390 /$ socsci5040056

United Nations., (2003). Focus on Ethiopia: Innovative approaches to emergency response.

United States Agency for International Development (USAID)., (2006). Report of voluntary agencies. Washington, D.C.: Voluntary Foreign Aid Service, Office of Material Resources.

Venter, E., (2017). Bridging the communication gap between Generation Y and the Baby Boomer generation. International Journal of Adolescence and Youth, 22(4), 497-507. doi:10.1080/02673843.2016.1267022

Waters, R. D., Tindall, N. T. J., \& Morton, T. S., (2010). Media catching and the journalist-Public relations practitioner relationship: How social media are changing the practice of media relations. Journal of Public Relations Research, 22(3), 241-264. doi:10.1080/10627261003799202

Walmsley, A. L. E., (2011). Closing the communication gap. Educational Horizons, 90(1), 25-26.

World Bank., (2016). World Development Report 2016: Digital Dividends. The World Bank Group.

Yang, Y. (Jenny), \& Simnett, R., (2020). Financial reporting by charities: Why do some choose to report under a more extensive reporting framework? Abacus, 56(3), 320-347. doi:10.1111/abac.12202

Zhang, N., \& Skoric, M. M., (2019). Making the news: environmental NGOs and their media visibility in China. Chinese Journal of Communication, 119. doi:10.1080/17544750.2019.1610468

Zheng, R., \& Cheok, A., (2011). Singaporean adolescents' perceptions of on-line social communication: An exploratory factor analysis, Journal Educational Computing Research, 45(2), 203-221.

Zhong, Z.-J., \& Lin, S., (2017). The antecedents and consequences of charitable donation heterogeneity on social media. International Journal of Nonprofit and Voluntary Sector Marketing, 23(1), doi:10.1002/nvsm.1585 